\title{
Export constraints facing Lesotho-based manufacturing enterprises
}

\author{
Authors: \\ Motšelisi C. Mokhethi ${ }^{1}$ \\ Adolf J. Vögel ${ }^{1}$ \\ Affiliations: \\ ${ }^{1}$ Department of Business \\ Management, University of \\ Pretoria, South Africa \\ Correspondence to: \\ Motšelisi Mokhethi \\ Email: \\ motselisi05@yahoo.co.uk \\ Postal address: \\ Department of Business \\ Administration, University \\ of Pretoria, Pretoria 0002, \\ South Africa \\ Dates: \\ Received: 25 Aug. 2014 \\ Accepted: 23 Feb. 2015 \\ Published: 17 July 2015 \\ How to cite this article: \\ Mokhethi, M.C. \& Vögel, A.J., \\ 2015, 'Export constraints \\ facing Lesotho-based \\ manufacturing enterprises', \\ Acta Commercii 15(1), Art. \\ \#284, 8 pages. http://dx.doi. \\ org/10.4102/ac.v15i1.284

\section{Copyright:} \\ (C) 2015. The Authors. \\ Licensee: AOSIS \\ OpenJournals. This work is \\ licensed under the Creative \\ Commons Attribution \\ License.
}

Read online:

Scan this QR code with your smart phone or mobile device to read online.
Orientation: Exporting is preferred by many enterprises as the mode of foreign entry as it requires less commitment of organisational resources and offers flexibility of managerial actions. However, enterprises face a number of challenges when attempting to initiate exports or expand their export operations.

Research purpose: This study was undertaken to determine the characteristics and composition of export barriers constraining exporting by Lesotho-based manufacturing enterprises.

Motivation for the study: Lesotho is faced with low destination diversity and low diversity in export products.

Research design, approach and method: Data was collected from 162 Lesotho-based manufacturing enterprises through a self-administered questionnaire.

Main findings: In its findings, the study firstly identified international constraints, distribution constraints and financial constraints as factors constraining exporting. Secondly, it was determined that three exporting constraints, all internal to the enterprise and all related to one factor (namely financial constraint) hampered exporting. Lastly, the ANOVA results revealed that the perceptions of export constraints differed according to the enterprise characteristics, enterprise size, ownership and type of industry.

Contribution/value-add: With the majority of enterprises in this study being identified as micro-enterprises, the government of Lesotho needs to pay particular attention to addressing the export needs of these enterprises in order to enable them to participate in exporting activities - especially considering that they can play a pivotal role in the alleviation of poverty, job creation and economic rejuvenation.

\section{Introduction}

Globalisation has prompted an increasing number of enterprises to develop strategies for entering markets outside their home markets (Bitzenis 2004:406; Johansson 2006:5; Osland, Taylor \& Zou 2001:153). According to Albaum, Duerr and Strandskov (2005:253), Halikias and Panayotopoulou (2003:340), and Leonidou et al. (2007:736), this entry into a foreign market can happen by either exporting to the market or by producing in the host country, with exporting being preferred as it requires less commitment of organisational resources and offers flexibility of managerial actions. However, enterprises face a number of challenges when attempting to initiate exports or expand their export operations (Leonidou 2004:280; Préfontaine \& Bourgault 2002:123; Viviers \& Calof 1999:918; Westhead, Wright \& Ucbasaran 2004:501).

As regards exports from Lesotho, statistics show that, with the exception of the years 2003, 2005 and 2007, there was an increase in exports during the period 1975-2008 (Lesotho Bureau of Statistics 2010:11). Between 1975 and 1984, exports grew by 10.4\%, whilst the period 1985 to 1994 saw a growth rate of $19.4 \%$. Exports reached a high of $122.3 \%$ (Lesotho Bureau of Statistics 2010:11) in 2000 following the signing of the Africa Growth Opportunity Act (AGOA).

This growth in exports can be attributed to a number of reasons, such as South African enterprises operating in Lesotho to avoid apartheid era trade sanctions in the 1980s (Lall 2005:1004; Salm et al. 2002:14), the Lesotho National Development Corporation's (LNDC) promotion of an exportoriented manufacturing sector in the early 1990s, especially textiles (Central Bank of Lesotho 2006:1), and the signing of AGOA in 2000. AGOA is a unilateral trade preference programme that grants eligible countries in sub-Saharan Africa (SSA) duty-free access to the US market (United States Department of Commerce n.d.). In particular, the signing of AGOA has led to an inflow of foreign direct investment (FDI) from Asia into the apparel and textile industries (Central Bank of Lesotho 2006:2; MIGA 2006:23). 
Clothing and garment exports have dominated Lesotho's exports (Central Bank of Lesotho 2006:2; Lesotho Bureau of Statistics 2003:3; Ng \& Yeats 2004:157), contributing between $63.2 \%$ and $89.9 \%$ of total exports between 1999 and 2008 . This could cause problems as the success of these products in recent years has been due to preferential access under AGOA, with AGOA set to expire in 2015 (Condon \& Stern 2011:5; Congressional Research Services 2003:10; Schaefer \& Markheim 2006:2). According to Sandrey et al. (2005:3), with low destination diversity the future of Lesotho's exports post-AGOA is bleak. An example of this drop in exports can be seen in 2005 when the World Trade Organisation's (WTO) Agreement on Textiles \& Clothing (ATC, also known as the Multi-Fibre Arrangement (MFA)) expired. This meant that the previous buyers of garments made in Lesotho could now buy unrestricted quantities of garments from places like China, causing a drop in exports from Lesotho (Bennet 2006:165). According to the Lesotho Bureau of Statistics (2010:15, 17), Lesotho's exports are predominantly destined for either South Africa or the American continent (including the US, Canada, Chile and Mexico). For instance, in 2008 exports destined for South Africa represented 30.9\% of total exports, whilst 53.5\% were destined for America, leaving only $15.6 \%$ for other markets.

In view of Lesotho's low destination diversity and low diversity in export products, as well as the AGOA agreement set to expire in 2015, this study was undertaken to determine the characteristics and composition of export barriers constraining exporting by Lesotho-based manufacturing enterprises.

\section{Literature review and hypotheses}

Over the years a number of studies have focused on export barriers (Crick \& Chaudhry 2000:30; Kaleka \& Katsikeas 1995:499). According to Leonidou (1995:6), the thrust of the research on export barriers occurred in the 1980s and early 1990s, even though the first empirical research appeared in the mid-1960s. Studies by Kaleka and Katsikeas (1995), Leonidou (2004), and Mahajar and Hashim (2001) focused on export constraints faced by enterprises from developed countries, with Leonidou (2004:283) in particular identifying two main groups of export barriers: internal and external. Tesfom and Lutz's (2006:269) study conducted in developing countries supports this classification and further subdivides the two main groups into enterprise, product, industry, market and macro-environmental barriers.

Studies by Crick and Chaudhry (2000), Da Silva and Da Rocha (2001), Katsikeas and Morgan (1994), Suárez-Ortega (2003), and Sullivan and Bauerschmidt (1989) aimed to determine whether perceived export barriers were influenced by various enterprise characteristics. In particular, Crick and Chaudhry (2000:33-34) revealed a number of barriers that exhibited statistically significant differences between groups of enterprises that operate in different industries, and Sullivan and Bauerschmidt (1989:21) found that managers in the same industry had similar perceptions towards certain sets of export barriers, whilst at the same time differing in perceptions towards other barriers. As a result it was hypothesised in this study that:

- $\mathbf{H}_{10}$ : The perceptions of managers in Lesotho-based manufacturing enterprises towards export barriers do not vary according to the industry they operate in.

- $\mathbf{H}_{1 \mathbf{a}}$ : The perceptions of managers in Lesotho-based manufacturing enterprises towards export barriers vary according to the industry they operate in.

Another enterprise characteristic related to perceived export barriers is enterprise size, as measured by the number of employees employed by an enterprise. Number of employees is preferred as research has revealed that managers are more willing to provide information on employment than sales volumes (Katsikeas \& Morgan 1994:21). Katsikeas and Morgan's (1994:25) findings found that smaller enterprises perceived more export problems than larger enterprises in three areas: information about the export market, product adaptation and exogenous logistical constraints. Da Silva and Da Rocha (2001:600-601) found that larger enterprises perceived themselves as being more affected by corruption in their international operations than small and medium enterprises did.

According to Katsikeas and Morgan (1994:20), and Suárez and Álamo-Vera (2005:260), larger enterprises are assumed to have greater resources, which are associated with lower levels of perceived risk in export market activities. Aaby and Slater (1989:21), however, found no relationship between enterprise size and exporting activity. It was therefore hypothesised in this study that:

- $\mathbf{H}_{20}$ : The perceptions of export barriers of managers in Lesotho-based manufacturing enterprises do not vary according to enterprise size.

- $\mathbf{H}_{2 \mathbf{a}}$ : The perceptions of export barriers of managers in Lesotho-based manufacturing enterprises vary according to enterprise size.

Lastly, the research focused on the relationship between ownership structure and export barriers. 'Ownership plays a key role in creating the incentives necessary to make risky decisions, including those associated with international expansion' (Lin 2010:368). According to Lin (2010), managers may be hesitant to make the risky but necessary move since their compensation is dependent on the performance of the enterprise. Ownership structure has been operationalised in different ways. Fu, Wu and Tang (2010:13) used sources of registered capital to categorise enterprise structure. They came up with three major classes: wholly foreignowned enterprises, joint ventures and wholly locally owned enterprises. Joint ventures also differed as to whether they had foreign control or domestic control.

Fu et al. (2010:13), in a study of Chinese manufacturing enterprises, found that wholly foreign-owned enterprises and joint ventures with foreign control have a higher probability of exporting and being persistent exporters. 
On the other hand, joint ventures with domestic control and wholly locally owned enterprises were not likely to export or to improve their export status.

Kim and Park (2011:5), however, differ from Fu et al. (2010:13). In their study of Korean manufacturing enterprises, they determined that concentrated ownership (irrespective of whether the dominant owners are of foreign or domestic origin) influences managers to perceive export constraints as less daunting than managers operating in enterprises that have dispersed ownership. Therefore it was hypothesised in this study that:

- $\mathbf{H}_{30}$ : The perceptions of managers in Lesotho-based manufacturing enterprises towards export barriers do not vary according to enterprise ownership structure.

- $\mathbf{H}_{3 \mathbf{a}}$ : The perceptions of managers in Lesotho-based manufacturing enterprises towards export barriers vary according to enterprise ownership structure.

\section{Methodology}

A judgement sampling approach was used, in that 7 out of 10 industrial areas in the country were visited and enterprises engaged in manufacturing were given a questionnaire to complete. The key-informant technique was employed, whereby key informants were managers directly responsible for international operations - in the absence of an international operations manager, the chief executive officer was approached.

Following a comprehensive literature study, the questionnaire had been developed on the basis of export barriers obtained from different authors, namely Da Silva and Da Rocha (2001), Leonidou et al. (2007), Leonidou (2004), Salm et al. (2002), Suárez-Ortega (2003), and Tesfom and Lutz (2006). The questionnaire consisted of both structured and open-ended questions (questions one and five), with the questionnaire being divided into two sections. Section A (questions one to six) comprised questions focused on enterprise characteristics, whilst Section B (questions 7.1 to 7.45) measured attitudes to export barriers using a five-point Likert scale, meaning that a total of 45 attitudes to export barriers were tested.

During the initial stage, the instrument underwent two rounds of evaluation: firstly by academics knowledgeable in the field of study, and secondly during the pilot study. A drop-and-pick-up approach was used: the researcher personally delivered the questionnaires to 171 Lesotho-based manufacturing enterprises. Of the 171, 9 enterprises failed to complete the questionnaire in the required three months, meaning that 162 usable questionnaires were received back, which translates into a $94.7 \%$ response rate.

After the questionnaires were returned, the data was first summarised using descriptive statistics. Secondly, the construct validity of the instrument was tested using an exploratory factor analysis, whilst Cronbach's alpha was used to measure the internal reliability of the instrument. Lastly, analysis of variance (ANOVA) was used to determine if enterprise characteristics influenced managers' perception of export barriers. The significance level selected for the ANOVA was 0.05 .

\section{Results and discussion Validity}

As indicated above, an exploratory factor analysis was conducted to determine the construct validity of the measuring instrument. The results of the factor analysis (Table 1), show factor 1 , named international constraints and is made up of 23 variables, factor 2 , named distribution constraints that consists of three variables, and factor 3 , named financial constraints and is made up of five variables. The factors account for $44.41 \%$ of the total variance in the data space. This is further supported by the fact that the eigenvalues for all three factors were above 1.00. Based on the factor-analysis results, 14 of the 45 variables were excluded as they either loaded high in more than one factor, or did not load high with any one factor. Upon inspection of the items making up each of the three factors, it was confirmed that the instrument did measure export barriers and as a result could be considered valid.

Factor 1 was named international constraints because when looking at the 23 variables in this factor it can be seen that they represent variables from both domestic and foreign environments and the interaction between these two environments. Ball et al. (2010:23, 25) define 'international environment' as the forces of the interaction between the domestic and foreign environments or between sets of foreign environmental forces.

Factor 2, distribution constraints, relates to issues of the enterprise's representation in overseas markets, whilst factor 3 , financial constraints, relates to the financial capabilities of an enterprise.

\section{Reliability}

The instrument used in this study can be considered reliable, as the alpha values for the three factors (Table 2) all scored above the recommended minimum alpha value of 0.70 (Cohen, Manion \& Morrison 2007:506; Pietersen \& Maree 2007:216).

\section{Demographic profile}

The results show that the majority of enterprises (35.80\%) that participated in the study were less than five years old, followed by $29.01 \%$ that had operated in the range of six to 10 years. The mature enterprises that had operated in Lesotho for 11 years or more (and made up the remaining three categories in the questionnaire) represent $35.19 \%$ of the total. Most of the enterprises (50.62\%) were micro-enterprises, that is, they had fewer than three employees, whilst large enterprises with 50 or more employees represented $24.69 \%$ of the respondents. In terms of ownership structure, wholly foreign-owned enterprises represented 32.09\%, wholly 
TABLE 1: Factor matrix with sorted rotated factor loadings.

\begin{tabular}{|c|c|c|c|c|}
\hline Coding & Variables & Factor 1 & Factor 2 & Factor 3 \\
\hline V33 & High insurance cost to cover products whilst in transit to foreign markets & 0.821 & $0.000 *$ & 0.000 \\
\hline V30 & Risk and variations in exchange rates & 0.743 & 0.000 & 0.000 \\
\hline V43 & Corruption in Lesotho & 0.737 & 0.000 & 0.000 \\
\hline V31 & Difficulty in supplying inventory abroad & 0.706 & 0.000 & 0.000 \\
\hline V32 & High transport costs for transporting products to foreign markets & 0.697 & 0.000 & 0.000 \\
\hline V44 & Corruption in the target market & 0.675 & 0.000 & 0.000 \\
\hline V41 & Inadequate container-handling facilities at the Lesotho railway terminal & 0.628 & 0.000 & 0.000 \\
\hline V45 & Political problems in Lesotho & 0.607 & 0.000 & 0.000 \\
\hline V29 & Difficulties meeting after-sales service to customers abroad & 0.574 & 0.000 & 0.000 \\
\hline V26 & The challenge of having to deal with foreign customers that have different cultural customs & 0.564 & 0.000 & 0.000 \\
\hline V50 & Political instability in the foreign markets that the enterprise wishes to serve & 0.546 & 0.000 & 0.000 \\
\hline V35 & Restrictions on the quantity that is allowed by foreign markets to enter their countries & 0.535 & $0.000 *$ & 0.000 \\
\hline V18 & Difficulty in meeting packaging requirements & 0.469 & 0.000 & 0.000 \\
\hline V40 & Poor telecommunication services & 0.414 & 0.000 & 0.000 \\
\hline V20 & Unable to adapt the enterprise's products to export market's requirements & 0.356 & 0.000 & 0.000 \\
\hline V28 & Difficulty in meeting foreign delivery dates & 0.486 & 0.000 & 0.000 \\
\hline V36 & Low labour productivity in Lesotho & 0.464 & 0.000 & 0.000 \\
\hline V46 & Industrial unrest in Lesotho resulting from employee strikes & 0.500 & 0.000 & 0.000 \\
\hline V37 & High cost of labour in Lesotho & 0.498 & 0.000 & 0.000 \\
\hline V17 & Difficulty in meeting product quality standards & 0.417 & 0.000 & 0.000 \\
\hline V24 & Lack of acceptance of Lesotho's products in the markets the enterprise wishes to serve & 0.485 & 0.000 & 0.000 \\
\hline V11 & Difficulty in maintaining control over foreign middlemen that the enterprise will be using & 0.000 & 0.993 & 0.000 \\
\hline V10 & Difficulty in obtaining reliable middlemen abroad & 0.000 & 0.941 & 0.000 \\
\hline V9 & Difficulty in communicating with clients overseas & 0.000 & 0.719 & 0.000 \\
\hline V13 & Lack of financial resources for market research & 0.000 & 0.000 & 0.971 \\
\hline V12 & Lack of financial resources to finance export sales & 0.000 & 0.000 & 0.935 \\
\hline V14 & Lack of excess manufacturing capacity for exports & 0.000 & 0.000 & 0.425 \\
\hline
\end{tabular}

*, All loadings less than 0.250 were indicated as 0.000 .

TABLE 2: Factor reliability as described by the Cronbach Alpha values.

\begin{tabular}{lc}
\hline Factor & Cronbach's Alpha \\
\hline 1. International constraints & 0.9249 \\
2. Distribution constraints & 0.9352 \\
3. Financial constraints & 0.7933 \\
\hline
\end{tabular}

locally owned enterprises $62.35 \%$ and jointly owned enterprises $5.56 \%$ of the respondents.

The respondents operated in 19 industries, but for the purposes of this study these were grouped into three industries, namely: textile and apparel (representing $54.32 \%$ of respondents), the leather industry (representing $8.64 \%$ of respondents), and enterprises classified as 'the rest' (representing the remaining $37.04 \%$ ). The enterprises comprised both exporting and nonexporting enterprises, but a further analysis of the exporting status of the enterprises determined four categories of enterprises: uninterested non-exporting enterprises (27.78\%), interested non-exporting enterprises $(26.55 \%)$, inactive exporters $(6.79 \%)$ and active exporters (38.88\%).

\section{Analysis of variance}

The three identified factors represented the dependent variables, whilst the three enterprise characteristics (type of industry, enterprise size and ownership structure) represented the independent variables.
TABLE 3: Factor 1 - International constraints and enterprise size.

\begin{tabular}{lcc}
\hline Variable & Mean* & Standard deviation \\
\hline Micro & $1.8427 \mathrm{a}$ & 0.6002 \\
Small & $1.4631 \mathrm{~b}$ & 0.8247 \\
Medium & $2.0793 \mathrm{a}$ & 0.7656 \\
Large & $2.1667 \mathrm{a}$ & 0.7539 \\
\hline
\end{tabular}

*, Means with the same letter are not significantly different.

\section{Size of the enterprise}

The results of the ANOVA indicated that the respondents' perceptions of factor 1 (international constraints) were influenced by the size of the enterprise (Table 3), with small manufacturing enterprises perceiving international constraints as being less of a constraint to exporting than did micro, medium and large enterprises.

This therefore means that the null hypothesis $\mathrm{H}_{20}$ (The perceptions of export barriers of managers in Lesotho-based manufacturing enterprises do not vary according to enterprise size) was rejected, whilst the alternative hypothesis $\mathrm{H}_{2 \mathrm{a}}$ (The perceptions of export barriers of managers in Lesotho-based manufacturing enterprises vary according to enterprise size) was accepted.

This finding contradicts the existing literature that states that smaller enterprises experience export constraints more severely than larger enterprises do (Katsikeas \& Morgan 
1994:25). In the case of Lesotho, most larger enterprises in the manufacturing sector are accounted for by foreign enterprises that operate predominantly in the textile and apparel industry (ECI Africa 2006:29; Lall 2005:1000; Lesotho MTICM 2008:23), and are export-oriented (Central Bank of Lesotho 2006:1; Lesotho MITM 2003:2; MIGA 2006:23). Some smaller enterprises do, however, cater for foreign markets with products such as carpets, tapestry, leather goods and handicrafts (Lesotho MITM 2000:9). According to the Lesotho MITM's (2000:8) definition, smaller enterprises cover both small-scale and micro-enterprises.

The findings of this study are interesting, as micro-enterprises perceive international constraints as more severe than do small enterprises, grouping micro-enterprises with medium and large enterprises. A possible explanation for this could be that it is the micro-enterprises, rather than small enterprises, that cater for foreign markets, with carpets, tapestry, leather goods and handicrafts.

\section{Industry in which the enterprise operates}

Secondly, the results of the ANOVA revealed a statistically significant difference (Table 4 ) in how respondents perceived factor 2 (distribution constraints) on the basis of the industry in which the enterprise operate.

As mentioned above, owing to the sample size and the number of industries being represented, enterprises were grouped into three industry types: textile and apparel manufacturing enterprises, leather manufacturing enterprises, and the enterprises classified as 'the rest', which comprised building materials, electrical appliances, artefacts, pottery, pharmaceutical, boxes and cartons, to mention but a few. The results showed that leather manufacturing enterprises perceived distribution constraints in the same way as did the textiles and apparel industry, whilst the textiles and apparel industry perceived distribution constraints in the same way as 'the rest' of the industries. However, the leather industry did not perceive distribution constraints as severely as did the 'the rest' of the industries.

This therefore means that the null hypothesis $\mathrm{H}_{60}$ (The perceptions of managers in Lesotho-based manufacturing enterprises toward export barriers do not vary according to the industry they operate in) was rejected, whilst the alternative hypothesis $\mathrm{H}_{6 \mathrm{a}}$ (The perceptions of managers in Lesothobased manufacturing enterprises toward export barriers vary according to the industry they operate in) was accepted.

These findings support previous studies that found that enterprises belonging to different industries within the

TABLE 4: Factor 2 - Distribution constraints and enterprise industry.

\begin{tabular}{lcc}
\hline Variable & Mean* & Standard deviation \\
\hline Textile & $2.3864 \mathrm{~b}, \mathrm{a}$ & 1.4716 \\
Leather & $1.8095 \mathrm{~b}$ & 1.1600 \\
The rest & $2.6167 \mathrm{a}$ & 1.6442 \\
\hline
\end{tabular}

*, Means with the same letter are not significantly different. manufacturing sector perceive export barriers differently, as they are likely to face different situations (Da Silva \& Da Rocha 2001:601; Leonidou 2004:284; Tesfom, Lutz \& Ghauri 2004:419).

In the case of Lesotho-based manufacturing enterprises, leather products are almost exclusively destined for South Africa (Sandrey et al. 2005:39, 58; UNCTAD 2012:19), a country that completely surrounds Lesotho and shares membership of the South African Customs Union (SACU 2013). On the other hand, some products from industries classified as 'the rest' are destined for the South Africa market (Lesotho MITM 2000:9), others are destined for Botswana (products such as medicine and pharmaceuticals), whilst yet others, such as milled products and handicrafts, are exported to Canada and the European Union (Maleleka \& Matlanyane 2005:31; UNCTAD 2012:19-20). This could contribute to the enterprises classified as 'the rest' perceiving distribution constraints as more severe than the enterprises in the leather industry.

\section{Ownership structure of the enterprise}

Next, the ANOVA results revealed that factor 1 (international constraints) is perceived differently by respondents depending on the ownership structure of the enterprise, in that jointly owned enterprises scored statistically significantly higher $(p<0.05$; see Table 5$)$ in their perception of international constraints than locally owned and foreignowned enterprises.

Lastly, the ANOVA results revealed that respondents also differed in their perception of factor 3 (financial constraints) depending on the ownership structure of the enterprise, in that locally owned enterprises scored statistically significantly higher $(p<0.05$; see Table 6$)$ for financial constraints than foreign-owned enterprises and jointly owned enterprises.

This therefore means that the null hypothesis $\mathrm{H}_{80}$ (The perceptions of managers in Lesotho-based manufacturing enterprises toward export barriers do not vary according to enterprise ownership structure) was rejected, whilst the alternative hypothesis $\mathrm{H}_{8 \mathrm{a}}$ (The perceptions of managers in Lesotho-based manufacturing enterprises toward export barriers vary according to enterprise ownership structure) was accepted.

TABLE 5: Factor 1 - International constraints and ownership structure.

\begin{tabular}{lcc}
\hline Variable & Mean* & Standard deviation \\
\hline $100 \%$ locally owned & $1.8849 \mathrm{~b}$ & 0.6676 \\
$100 \%$ foreign-owned & $1.7901 \mathrm{~b}$ & 0.7512 \\
Joint ownership & $2.5894 \mathrm{a}$ & 0.8255 \\
\hline
\end{tabular}

*, Means with the same letter are not significantly different.

TABLE 6: Factor 3 - Financial constraints and ownership structure.

\begin{tabular}{lcc}
\hline Variable & Mean* & Standard deviation \\
\hline $100 \%$ locally owned & $3.5505 \mathrm{a}$ & 1.0761 \\
$100 \%$ foreign-owned & $1.7846 \mathrm{~b}$ & 0.8819 \\
Joint ownership & $2.3333 \mathrm{~b}$ & 1.3077 \\
\hline
\end{tabular}

*, Means with the same letter are not significantly different. 
The ANOVA results that found that jointly owned enterprises scored statistically significantly higher for perception of international constraints than locally owned and foreignowned enterprises differ from the existing literature, which suggests that enterprises with domestic control will perceive exporting constraints as more severe than enterprises with foreign control (Fu et al. 2010:13). A possible explanation for this finding is that with joint ownership, these enterprises experience the interaction between the domestic and foreign environments more severely than wholly locally owned and wholly foreign-owned enterprises do.

The finding that locally owned enterprises perceive financial constraints more severely than both foreign-owned and jointly owned enterprises is consistent with the existing literature, which suggests that enterprises with domestic control will perceive exporting constraints more severely than enterprises with foreign control (Fu et al. 2010:13). The finding further supports the literature that holds that locally owned, predominantly small enterprises would have difficulty in accessing financing. According to the World Bank (2007:70), locally owned enterprises in Lesotho are more likely to encounter serious problems in accessing credit than foreign-owned enterprises would. This is due to the fact that foreign-owned enterprises do not have to rely solely on the domestic financial system, as they can receive financing from their home country and their parent enterprises. According to the Lesotho MTICM (2008:36), most small enterprises in Lesotho rely on personal savings to finance their start-up and running costs, as they are unable to furnish the necessary security for loans needed by financial institutions.

The Lesotho MITM (2000:17) indicates that the financial sector in Lesotho is underdeveloped and it targets consumers at particular levels of income, as well as medium and large-scale corporate clients. According to the Lesotho MITM (2000:17), in effect there are no second-tier banking institutions that can mobilise savings and extend credit to small enterprises. The Lesotho MITM (2000:15-16) further indicates that attempts to establish alternative financial mechanisms to enable small and micro-enterprises to access financing failed, as the different schemes that were put in place collapsed.

The financial constraint amongst small, predominantly local, enterprises is further exacerbated by the export promotion structure, which is focused mostly on medium and large foreign enterprises engaged in the textile and apparel industry. Shakya (n.d.:10) indicates that the LNDC, charged with the implementation of the country's export and investment promotion programmes, works with medium and large enterprises, and because of its extreme concentration on apparel, it actually functions as a de facto garment promotion agency. The Lesotho MITM (2000) is also quoted as saying that:

... until very recently, economic growth and development in Lesotho were identified solely with medium and largescale enterprises. The small and micro-enterprises sector was seen as unproductive non-growth-enhancing. Consequently, industrial development and investment strategies and policies emphasised the need to focus on promotional efforts to attract foreign investment into the large-scale industrial sector. (p. 12)

\section{Descriptive statistics}

The mean scores of export constraints (Table 7) indicate that there are three export constraints, namely lack of financial resources for market research, lack of financial resources to finance export sales, and lack of excess manufacturing capacity for exports. Similar findings have been reported by other studies, for example, Fillis' (2002:917) list of exporting constraints included limited production capacity and lack of financial resources, whilst Da Silva and Da Rocha (2001:600) found the dominant export barrier to be lack of financial assistance.

The financial constraints have a link to the context of Lesotho's business environment. According to various reports on Lesotho, access to finance is difficult for a number of reasons, especially for smaller enterprises. The Lesotho MTICM (2002:11) and the World Bank (2007:69) indicate that lending is restricted by the limited availability and enforceability of collateral. The World Bank (2007:6869) further indicates that the financial sector in Lesotho is very small and concentrated, and this being so, banks engage in what appears to be de facto cartel-like pricing, with high service charges and lending rates consistently higher than those of neighbouring countries, despite operating within the same common market. It is further noted that the absence of adequate credit assessment information tools, such as a credit bureaux, contributes to restricted credit.

\section{Conclusion}

The aim of the study was to investigate export constraints facing Lesotho-based manufacturing enterprises in view of Lesotho's low destination diversity and low assortment of export products. In addition, the study was conducted because the AGOA agreement, which led to an inflow of FDI into apparel and textile industries, was set to expire in 2015. This study determined that Lesotho-based manufacturing enterprises face three exporting constraints: lack of financial resources for market research, lack of financial resources to finance export sales, and lack of excess manufacturing capacity for exports. The three export barriers are all internal to the enterprise and all loaded under factor 3: financial constraints. The ANOVA results further revealed that locally owned enterprises experience these constraints much more severely than do both foreign-owned and jointly owned enterprises.

With the majority of enterprises in this study being micro as well as being local, the government of Lesotho needs to pay particular attention to addressing the needs of small locally owned enterprises' constraints in order to enable them to participate in exporting activities - especially considering 
TABLE 7: Perceived exporting constraints from Lesotho-based manufacturing enterprises.

\begin{tabular}{|c|c|c|}
\hline Coding number & Exporting constraints & Mean scores \\
\hline$\overline{\mathrm{V} 13}$ & Lack of financial resources for market research & 3.19 \\
\hline V12 & Lack of financial resources to finance export sales & 3.15 \\
\hline V14 & Lack of excess manufacturing capacity for exports & 3.04 \\
\hline V21 & Lack of awareness of export assistance available in Lesotho & 2.82 \\
\hline V43 & Corruption in Lesotho & 2.53 \\
\hline V11 & Difficulty in maintaining control over foreign middlemen that the enterprise will be using & 2.44 \\
\hline V10 & Difficulty in obtaining reliable middlemen abroad & 2.44 \\
\hline V32 & High transport costs for transporting products to foreign markets & 2.38 \\
\hline V9 & Difficulty in communicating with clients overseas & 2.38 \\
\hline V49 & Difficulty in matching competitors' prices & 2.37 \\
\hline V30 & Risk and variations in exchange rates & 2.32 \\
\hline V33 & High insurance cost to cover products whilst in transit to foreign markets & 2.27 \\
\hline V44 & Corruption in the target market & 2.17 \\
\hline V42 & Unsuitable storage facilities for containers at the Lesotho railway terminal & 2.14 \\
\hline V23 & Lack of own internationally recognised brand names & 2.02 \\
\hline V28 & Difficulty in meeting foreign delivery dates & 2.01 \\
\hline V31 & Difficulty in supplying inventory abroad & 1.99 \\
\hline V29 & Difficulties meeting after-sales service to customers abroad & 1.98 \\
\hline V50 & Political instability in the foreign markets that the enterprise wishes to serve & 1.94 \\
\hline V37 & High cost of labour in Lesotho & 1.89 \\
\hline V45 & Political problems in Lesotho & 1.77 \\
\hline V36 & Low labour productivity in Lesotho & 1.74 \\
\hline V26 & The challenge of having to deal with foreign customers that have different cultural customs & 1.67 \\
\hline V35 & Restrictions on quantities allowed by foreign markets to enter their countries & 1.59 \\
\hline V40 & Poor telecommunication services & 1.59 \\
\hline V18 & Difficulty in meeting packaging requirements & 1.58 \\
\hline V46 & Industrial unrest in Lesotho resulting from employee strikes & 1.56 \\
\hline V20 & Unable to adapt the enterprise's products to export market's requirements & 1.48 \\
\hline
\end{tabular}

that they play a pivotal role in the alleviation of poverty, job creation and economic rejuvenation. In Lesotho there are institutions such as the LNDC and the Basotho Enterprise Development Corporation (BEDCO), which are charged with export and investment promotion in the country. These agencies should ensure that local enterprises gain access to incentives that are mostly given to the large and medium enterprises, specifically those incentives that would influence their financial status, such as short-term and long-term loans, credit guarantee assistance offered to exporters, and import VAT credit facility for the local purchasing of raw material and capital goods.

Furthermore, with few jointly owned manufacturing enterprises in Lesotho, locally owned enterprises are denied the opportunity to access additional capital that foreign enterprises could bring into the venture. It also means that when foreign enterprises depart, they will not leave behind positive spillovers. Relationships between enterprises would normally form if each partner had something to offer. Whilst locally owned enterprises in Lesotho, owing to their limited capabilities and capacity, might not possess financial resources to bring into the joint venture, their local knowledge would still make them valuable to a joint-venture partner. However, the government should provide incentives to investors who opt for joint ventures so that locally owned enterprises could gain expertise and additional funds as a result of working with larger enterprises. Incentives could take the form of tax relief, low-interest loans, low prices on land leasing, as well as electricity and water incentives already widely in use in other countries.

\section{Limitations and directions of future research}

A limitation of this study was the lack of a reliable list of manufacturing enterprises in Lesotho, as this could have affected the extent to which the findings could be generalised to all Lesotho-based manufacturing enterprises. It meant that a non-probability approach had to be adopted in selecting the sample. Also, the use of a single informant in an enterprise could possibly be seen as a problem, as it could have introduced measurement error due to individual bias.

Future research could focus on determining why microenterprises perceive international constraints as severely as medium and large enterprises and not in line with those of small enterprises. Also, future research should investigate why the leather industry has lower perceptions of distribution constraints than enterprises from industries classified in this study as 'the rest'. It would also be of interest to investigate why almost $30 \%$ of enterprises that participated in the study were not interested in exporting. 


\section{Acknowledgements}

\section{Competing interests}

The authors declare that they have no financial or personal relationship(s) that may have inappropriately influenced them in writing this article.

\section{Authors' contributions}

M.C.M. and J.V. (both for the University of Pretoria) equally contributed to the research and writing of this article.

\section{References}

Aaby, N.E. \& Slater, S.F., 1989, 'Management influences on export performance: A review of the empirical literature 1978-88', International Marketing Review 6(4), 7-26. http://dx.doi.org/10.1108/EUM0000000001516

Albaum, G., Duerr, E. \& Strandskov, J., 2005, International marketing and expor management, 5th edn., Prentice Hall, London.

Ball, D.A., Geringer, J.M., Minor, M.S. \& Mcnett, J.M., 2010, International business: The challenge of global competition, 12th edn., McGraw-Hill Irwin, New York.

Bennet, M., 2006, Lesotho's export textiles and garment industry, viewed 12 June 2013, from http://library.fes.de/pdf-files/iez/03796/12lesotho.pdf

Bitzenis, A., 2004, 'Is globalisation consistent with the accumulation of FDI inflows in the Balkan countries?', European Business Review 16(4), 406-425. http://dx.doi. org/10.1108/09555340410547017

Central Bank of Lesotho, 2006, Annual report 2005, Central Bank of Lesotho, Maseru.

Cohen, L., Manion, L. \& Morrison, K., 2007, Research methods in education, 6th edn. Routledge, London.

Condon, N. \& Stern, M., 2011, The effectiveness of African Growth and Opportunity Act (AGOA) in increasing trade from LEAST developed countries, viewed 12 June 2013 from http://r4d.dfid.gov.uk/PDF/Outputs/SystematicReviews/AGOA-Report.pdf

Congressional Research Services, 2003, US trade and investment relationship with sub-Saharan Africa: The African Growth and Opportunity Act and beyond, Congressional Research Service, Washington.

Crick, D. \& Chaudhry, S., 2000, 'UK agricultural exporters' perceived barriers and government assistance requirements', Marketing Intelligence and Planning 18(1) 30-38. http://dx.doi.org/10.1108/02634500010308576

Da Silva, P.A. \& Da Rocha, A., 2001, 'Perception of exporting barriers to Mercosur by Brazilian firms', International Marketing Review 18(6), 589-610. http://dx.doi. org/10.1108/EUM0000000006296

$\mathrm{ECl}$ Africa, 2006, Capacity building action plan for the private sector in Lesotho, $\mathrm{ECI}$ Africa, Woodmead.

Fillis, I., 2002, 'Barriers to internationalisation: An investigation of the craft microenterprise', European Journal of Marketing 36(7/8), 912-927. http://dx.doi. org/10.1108/03090560210430872

Fu, D., Wu, Y. \& Tang, Y., 2010, The effects of ownership structure and industry characteristics on export performance. Discussion paper viewed 24 October 2011 from http://www.UWA.edu.au/_data/assets/Pdf file/007/888406/10

Halikias, J. \& Panayotopoulou, L., 2003, 'Chief executive personality and export involvement', Management Decision 41(4), 340-349. http://dx.doi. org/10.1108/00251740310468072

Johansson, J.K., 2006, Global marketing: Foreign entry, local marketing, and global management, 4th edn., McGraw-Hill, Singapore.

Kaleka, A. \& Katsikeas, C.S., 1995, 'Export problems: The relevance of export development', Journal of Marketing Management 11, 499-515. http://dx.doi. org $/ 10.1080 / 0267257 X .1995 .9964361$

Katsikeas, S. \& Morgan, R.E., 1994, 'Differences in perception of exporting problems based on firm size and export market experience', European Journal of Marketing 28(5), 17-35. http://dx.doi.org/10.1108/03090569410062014

Kim, S. \& Park, D., 2011, Ownership structure of firms and their export performance: Evidence from Korea, viewed 4 July 2013, from http://www.Egc.hss.ntu.edu.sg/ research/workingpp/Documents/2011

Lall, S., 2005, 'FDI, AGOA and manufactured exports by a landlocked, least developed African economy: Lesotho', Journal of Development Studies 41(6), 998-1022. http://dx.doi.org/10.1080/00220380500155254

Leonidou, L.C., 1995, 'Export barriers: Non-exporters' perceptions', International Marketing Review 12(1), 4-25. http://dx.doi.org/10.1108/02651339510080070

Leonidou, L.C., 2004, 'An analysis of export barriers hindering small business export development', Journal of Small Business Management 42(3), 279-302. http:// dx.doi.org/10.1111/j.1540-627X.2004.00112.x

Leonidou, L.C., Katsikeas, C.S., Palihawadana, D. \& Spyropoulou, S., 2007, 'An analytical review of the factors stimulating smaller firms to export: Implications for policy-makers', International Marketing Review 24(6), 735-770. http://dx.doi. org/10.1108/02651330710832685
Lesotho Bureau of Statistics, 2003, Foreign Trade Statistics. Statistics Report \#05, Government of Lesotho, Maseru.

Lesotho Bureau of Statistics, 2010, Foreign Trade Statistics. Statistics Report \#08, Government Printer, Maseru.

Lesotho MITM (Ministry of Industry, Trade and Marketing), 2000, White paper on a national strategy for the development and promotion of small business sector in Lesotho, Government Printer, Maseru.

Lesotho MITM (Ministry of Industry, Trade and Marketing), 2003, Integrated framework: Diagnostic trade integration study. Document for consultation and discussion, Government of Lesotho, Maseru.

Lesotho MTICM (Ministry of Trade and Industry, Cooperatives and Marketing), 2002, White paper on the development and promotion of small business: 'Making Lesotho a good place to do business', Government of Lesotho, Maseru.

Lesotho MTICM (Ministry of Trade and Industry, Cooperatives and Marketing), 2008, The state of small enterprise in Lesotho, Government of Lesotho, Maseru.

Lin, X., 2010, 'State versus private MNCs from China: Initial conceptualizations', International Marketing Review 27(3), 366-380. http://dx.doi.org/10.1108/ 02651331011048023

Mahajar, A.J. \& Hashim, M.K., 2001, 'Exporting problems of Malaysian SMEs: A recent survey', Asian Economic Review 43(3), 384-394.

Maleleka, D. \& Matlanyane, R., 2005, Trade performance review 2005: Lesotho, viewed 24 May 2013, from http://www.sadctrade.org/file/TPR\%20Lesotho

MIGA (Multilateral Investment Guarantee Agency), 2006, Benchmarking FD competitiveness in Sub-Saharan African countries, viewed 28 June 2013, from http://www.fdi.net/documents/WorldBank/databases/snapshot_africa/docs/ snapshot_africa.pdf

$\mathrm{Ng}$, F. \& Yeats, A., 2004, 'Export profiles of small land locked countries: What are their implications for Lesotho?', The South African Journal of Economics 72(1), 153-187. http://dx.doi.org/10.1111/j.1813-6982.2004.tb00108.x

Osland, G.E., Taylor, C.R. \& Zou, S., 2001, 'Selecting international modes of entry and expansion', Marketing Intelligence \& Planning 19(3), 153-161. http://dx.doi. org/10.1108/02634500110391690

Pietersen, J. \& Maree, K., 2007, 'Standardisation of a questionnaire', in K. Maree (ed.), First steps in research, p. 216, Van Schaik, Pretoria.

Préfontaine, L. \& Bourgault, M., 2002, 'Strategic analysis and export behaviour of SMEs: A comparison between the United States and Canada', Internationa Small Business Journal 20(2), 123-138. http://dx.doi.org/10.1177/02662426022 02001

SACU (South African Customs Union), 2013, South African Customs Union, viewed 12 June 2013, from http://www.sacu.int/

Salm, A., Grant, W.J., Green, T.J., Haycock, J.R. \& Raimondo, J., 2002, Lesotho Garment Industry Subsector Study for the Government of Lesotho, DFID, London.

Sandrey, R., Maleleka, D., Matlanyane, A. \& Van Seventer, D.E., 2005, Lesotho: Export diversification study. Tralac Working Paper 10/2005, viewed 2 April 2013, from www.tralac.org

Schaefer, B.D. \& Markheim, D., 2006, 'The free trade future of AGOA', Heritage Foundation 1108, 1-5.

Shakya, M., n.d., Lesotho: The state's role in building a critical mass for competitivenes in apparel exports, viewed 28 June 2011, from http://www.siteresources. worldbank.org/AfricaExt.../Lesotho_success.pdf

Suárez-Ortega, S., 2003, 'Export barriers: Insights from small and medium-sized firms', International Small Business Journal 21(4), 403-419. http://dx.doi. org/10.1177/02662426030214002

Suárez-Ortega, S. \& Álamo-Vera, F.R., 2005, 'SMEs' internationalization: Firms and managerial factors', International Journal of Entrepreneurial Behaviour \& Research 11(4), 258-279. http://dx.doi.org/10.1108/13552550510603298

Sullivan, D. \& Bauerschmidt, A., 1989, 'Common factors underlying barriers to export: A comparative study in the European and US paper industry', Management International Review 29(2), 17-32.

Tesfom, G. \& Lutz, C., 2006, 'A classification of export marketing problems of small and medium sized manufacturing firms in developing countries', International Journal of Emerging Markets 1(3), 262-281. http://dx.doi. org $/ 10.1108 / 17468800610674480$

Tesfom, G., Lutz, C. \& Ghauri, P., 2004, 'Comparing export marketing channels: Developed versus developing countries', International Marketing Review 21(4/5), 409-422. http://dx.doi.org/10.1108/02651330410547117

UNCTAD (United Nations Conference on Trade and Development), 2012, Who is benefiting from trade liberalization in Lesotho? A gender perspective, viewed 24 May 2013, from http://www.UNCTAD.org/PublicationsLibrary?osg2012d2 en.pdf

United States Department of Commerce, n.d., AGOA: African Growth and Opportunities Act, viewed 12 June 2013, from http://www.agoa.gov/

Viviers, W. \& Calof, J., 1999, 'A framework for creating an export society in South Africa', International Journal of Social Economics 26(7/8/9), 915-924.

Westhead, P., Wright, M. \& Ucbasaran, D., 2004, 'Internationalisation of private firms: Environmental turbulence and organisational strategies and resources', Entrepreneurship and Regional Development 16, 501-522. http://dx.doi. org/10.1080/0898562042000231929

World Bank, 2007, Lesotho: An assessment of the investment climate, Private Sector Unit, Africa Region, Washington. 